\title{
Effect of Environmental Management Guidelines on Home Safety level among Elderly People
}

\section{Nermeen Mahmoud Abd-Elaziz ${ }^{1}$, Ola Gouda Mohamed Elshiekh ${ }^{2}$ Ola Ezzat Eltohamy Mohamed ${ }^{2}$, Soher Ahmed Awad ${ }^{3}$}

(1) Assistant Professor of Gerontological Nursing, Faculty of Nursing, Assiut University.

(2) Lecturer of Gerontological Nursing, Faculty of Nursing, Damanhour University.

(3) Lecturer of Gerontological Nursing, Faculty of Nursing, Assiut University..

Email: nermeenbarakat@aun.edu.eg

Tel : 01010064423

\section{Abstract}

The home safety is an imperative issue, especially for senior people; hence the changes of the lodging environment are essential for their safety and health. Study aim: to detect the effect of environmental management guidelines on home safety level among elderly people. Design: Quasi-experimental research design (pre and posttest). Setting: Participants were selected from outpatient clinics of Assiut university hospital, Assiut governorate. Tools: three tools were utilized. Tool I: A structured questionnaire includes demographic characteristics. Tool II: Home Safety Self-Assessment scale. Tool III: Home safety level questionnaire. Results: It was found that elders' home safety level score increased from $36.3 \%$ in pretest to $54.4 \%$ in posttest with a high statistical significant difference $\mathrm{P}=0.000$.Added to, there were statistically significant relations between age, residence, and educational level and home safety level of the studied sample. Conclusion: Numerous seniors are living in potentially unsafe environment and the application of environmental management guidelines was effective in increasing their home safety level. Recommendation: More authoritative work in this zone should be carried out.

Key Words: Elderly, Environment, Guidelines, Home Safety, Management.

\begin{tabular}{|l|l|l|}
\hline Received : 5/7/2021 & Accepted : 13/7/2021 & Published : 1/1/2022 \\
\hline
\end{tabular}

\section{Introduction}

Individuals around the world are living for a longer life span. Nowadays, for the primary time in history, most individuals can anticipate to live into their sixties and past. By 2050, the world's populace matured 60 a long time and more seasoned is anticipated to add up to 2 billion, up from 900 million in 2015. Nowadays, 125 million individuals are matured 80 a long time or more seasoned. By 2050, $80 \%$ of all more seasoned individuals will be living in low and middle-income nations ${ }^{(\mathbf{1})}$.

In Egypt, the percent of individuals 60 years and more was 4.6\% in 1976, 6.65\% in 1996, growing to $6.8 \%$ in 2006 , and $6.8 \%$ within 2015 . The rate is $9.2 \%$ in 2021 , and it is anticipated to reach $20.8 \%$ in 2050 . This implies that, around 20 million Egyptians will be categorized as elderly by that time ${ }^{(2)}$. 
Home security includes taking time to examine the domestic environment to discover the covered up threats which will increment the risk of harm or indeed passing. Exposures and wellbeing dangers within the homes environment are fundamentally critical since of the expansive sum of time elderly individuals spend there ${ }^{(3)}$.

Many elderly people's time is spent in their houses; especially those with comorbidities, declined functional capacities are subsequently more liable for wellbeing dangers related to unsafe houses. Structurally destitute housing, due to insufficient construction or modifications can increase the likelihood for slipping, fractures, bleeding, unintentional injuries, limited physical activities, stress, and isolation ${ }^{(\mathbf{3})}$.

Domestic injuries as a result of unsafe environment represent $18 \%$ to $25 \%$ of all mischances all over the world. Home accidents lead to significant morbidity and mortality in the elderly and a load to their family. Roughly, more than $55 \%$ of older adults exposed to home accidents and about 3.9 million elderly people die related to unintentional home injuries globally every year. This decreases an elderly's capacity to move freely and negatively impacting their quality of life ${ }^{(4)}$.

Awesome numbers of theses accidental wounds may be avoided by careful review of the domestic. Home security may regularly be accomplished by distinguishing covered up threats and taking straight forward steps to redress them ${ }^{(3)}$. There are numerous regions inside the domestic that can contain cowered up and neglected perils. Free carpeting and floor coverings, uneven tile and worn wooden flooring, and free step treads can all lead to slips and falls ${ }^{(5)}$.

Gerontological nurses have a vital role in protecting the security of elderly people regardless the location where health care services are rendered to the client. This can be achieved through performing adequate assessment of safety needs, identifying the environmental circumstances and hazards, and designing educational programs aimed at safety improvement for them.

\section{Significance of the Study:-}

Older adults are rapidly growing proportion of the population in Egypt, and are increasingly at risk for home accidental injuries. Although, several previous studies conducted in Egypt ${ }^{(687)}$ reflected high percentage of unintentional home accidents and injuries among 
elderly people as a result of unsafely and hazardous environment .There is limited studies focused on designing intervention programs aimed to identify the potential hazards, home safety level, and implement environmental modification in order to limit this problem. From this point, researchers attended to conduct this study.

\section{Study Aim:}

To detect the effect of environmental management guidelines on home safety level among elderly people.

Study hypothesis:

- Environmental management guidelines will increase the home safety level for the elderly people.

\section{Null hypothesis:}

- Environmental management guidelines will not increase the home safety level for elderly people.

\section{Subjects and Method:}

\section{Research design:-}

Quasi-experimental research design (pre and posttest) was used in this study.

\section{Setting:-}

The study was conducted in outpatient's clinics of Assuit university hospital at Assuit governorate (hypertension, diabetes, orthopedic, and ophthalmology clinics) which have higher flow rates of the elderly people, and then home visits were conducted for participants to evaluate the home safety level and to give the educational sessions.

\section{Sample:-}

This study was conducted on a convenient sample of 204 elderly persons attended to the previously mentioned settings; the sample size was calculated by EP/Info version 3 with 95\% confidence interval.

\section{Inclusion criteria:}

- Elderly persons aged 60 years and above who agree to participate.

- Alert and able to communicate. 
Study tools:

\section{Three tools were utilized to collect the data of this study:}

Tool I: A structured interview questionnaire sheet developed by the researchers for collecting the needed data. It included demographic characteristics as; age, gender, residence, marital status, current \& previous occupation, and the level of education.

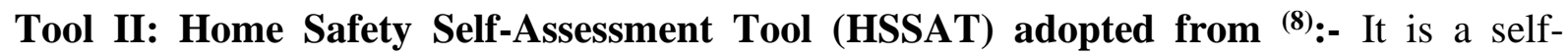
reported tool used to identify and mitigate environmental hazards within the home, such as uneven floors, torn carpets, and loose handrails.

Tool III: Home Safety Level Questionnaire ${ }^{(9)}$ :- Included 10 questions likert scale to assess the safety level at home, scoring: 0 , with sequential left to right scores of $1,2,3$. As Always $=0 \quad$ usually $=1$ sometimes $=2$ No usually alone $=3$. The higher the score, the more concern regarding the safety issue. People who had score $60 \%$ or less considered low safety issue, and High safety issue if more than $60 \%$.

- These second and third tools were used two times, before the application of home environmental management guidelines as a pretest, and two months after the guidelines application as posttest.

\section{Validity \& Reliability of the tools:-}

Tools were tested for its content validity by a group of five experts in gerontological health nursing. The required modifications were done. Testing reliability of the study tools was done by alpha Cronbach's test and the test result was $0.8 \%$.

\section{Methodology:-}

\section{I- Administrative stage:}

- An official letter approval was obtained from the Dean of the Faculty of Nursing, to carry out the study. The letter includes a permission to carry out the study and explained the purpose and nature of the study.

\section{II- Pilot study:}

- It carried out prior to beginning of data collection on (10 elderly patients) who excluded from the study. Pilot study aimed to test the tools clarity and the time needed for fulfilling it. Based on the results of the pilot study, the necessary modifications in sheets were done. 


\section{III- Ethical Consideration:}

Research proposal was approved from the ethical committee in the faculty of nursing and from the selected setting of the study. There was no risk for the study subjects during the conducting of the research. The study was following ethical principles adopted in clinical research. Confidentiality and anonymity was assured. Participants had the right to refuse to participate and or withdraw from the study without any rational any time.

\section{VI- Data collection:}

The duration of the study lasted within one year; starting from the beginning of June 2019 to the end of May 2021, data collection was through 2 days weekly, during the morning shift (9.00 am$2.00 \mathrm{Pm})$ at the previously mentioned settings. During the first personal interview, the aim was explained and the agreement for voluntary participation was taken. Three home visits and two educational sessions were applied. Posttest was done after giving the educational guideline by two months.

\section{V- Statistical analysis:}

The obtained data were reviewed, prepared for computer entry, coded, analyzed and tabulated. Descriptive statistics (frequencies, percentage, mean and standard deviation) were done using computer program SPSS version 22, Excel 2016, analysis of variance done by using chi-square test $\mathrm{P}$ - Value $<0.05$.

\section{The Home Environmental Management Guidelines}

These have been developed based on the review of relevant literatures and available resources. A brochure was prepared including summarized simple guidelines about environmental management, bathroom and toilets, furniture, floor surfaces lighting, passageways, external areas, and security of the environment which was given to every study participant.

\section{General objective of the Health Literacy Program:-}

Increase home safety level for elderly people.

\section{Specific objectives:-}

To determine the effect of home environmental management guidelines on safety level among the elderly people. 


\section{Field work}

\section{I- Assessment stage:}

Based on the pretest assessment of home safety level the educational guidelines were designed.

\section{II-Planning stage:}

The arrangements of conducting the guidelines were done during this stage; the educational sessions and the time needed were decided. Other facilities were checked and arranged during this phase such as the teaching methods, audiovisual aids and handout.

Teaching Time: the time of teaching was decided according to the elderly time and the researcher's.

Teaching methods and materials: It was prepared before implementing the guidelines to prepare simple teaching methods to be used; as discussions, power-point presentation, demonstration, and using media as pictures, handouts, posters \& videos.

\section{III- Implementation phase:}

Firstly the demographic data and the home Safety Self-Assessment Tool (HSSAT) were filled individually from each participant by the researchers in the outpatient clinics, and then the researchers asked participants to actually see and evaluate their home safety level by using the third tool and to provide the educational guidelines that aimed to improve their home safety level. Three home visits were designed for each respondent took about 30-40 minutes and two educational sessions applied.

- At the first home visit: Researchers introduced themselves, clarified the aim of the study, then the researcher evaluated the home safety level by using the third tool which covered environmental items as; bathroom, stairway, passageway, grab bars, and home security. After that the first educational session was conducted by using of simple language, a concise introduction about the definition of home safety, home hazards and potential risks for elderly was given.

- The $2^{\text {nd }}$ home visit: during it, the second educational session was applied focusing on implementing the educational guidelines that aimed at elderly home safety improvement. It covered the needed environmental modifications inside home and the preventive measures for home accidents. 
- A brochure in simple Arabic language riches with colorful figures about environmental management, bathroom and toilets, furniture, floor surfaces lighting, passageways, external areas, and security of the environment which was given to every study participant.

\section{IV- Evaluation phase:}

- During this phase, the third and the last home visit for each respondent was conducted after two months of guidelines application using the same second and third study tools as posttest to evaluate the effect of guidelines on the elders' home safety level. It took about 40 minutes for each visit.

\section{Results:}

\section{Table (1): Distribution of participants' demographic data.}

\begin{tabular}{|l|c|c|}
\hline Demographic data & No. (204) & \% \\
\hline Age (years): & \multicolumn{2}{|l|}{} \\
\hline 60- 69 years & 95 & 46.6 \\
\hline$\geq 70-85$ years & 109 & $\mathbf{5 3 . 4}$ \\
\hline Range & $60-85$ & \\
\hline Mean \pm SD & $\mathbf{7 0 . 4 \pm 7 . 0}$ & \\
\hline Gender: & \multicolumn{2}{|l|}{} \\
\hline Male & 81 & 39.7 \\
\hline Female & 123 & $\mathbf{6 0 . 3}$ \\
\hline Residence: & \multicolumn{2}{|l|}{} \\
\hline Urban & 68 & 33.3 \\
\hline Rural & 136 & $\mathbf{6 6 . 7}$ \\
\hline Education: & & \\
\hline Illiterate & 163 & $\mathbf{7 9 . 9}$ \\
\hline Read and Write & 25 & 12.3 \\
\hline Secondary & 12 & 5.8 \\
\hline University & 4 & 2.0 \\
\hline
\end{tabular}

Table 1: cleared that $53.4 \%$ of the studied sample aged 60-69 years old, with mean age was $70.4 \pm 7.0$, and three fifths of them were females. Regarding residence, it was observed that $(66.7 \%)$ of them were from rural areas and most of participants were illiterate. 
Table (2): Comparison between the participants' responses concerning to home safety items at pre and posttest.

\begin{tabular}{|c|c|c|c|c|c|c|c|c|}
\hline \multirow[t]{2}{*}{ Home safety items } & & & & & & & & \\
\hline & $\begin{array}{l}\text { Pretest } \\
(\mathrm{N}, \%)\end{array}$ & $\begin{array}{c}\text { Posttest } \\
(\mathrm{N}, \%)\end{array}$ & $\begin{array}{l}\text { Pretest } \\
(\mathrm{N}, \%)\end{array}$ & $\begin{array}{l}\text { Posttest } \\
(\mathrm{N}, \%)\end{array}$ & $\begin{array}{l}\text { Pretest } \\
(\mathrm{N}, \%)\end{array}$ & $\begin{array}{l}\text { Posttest } \\
(\mathrm{N}, \%)\end{array}$ & $\begin{array}{l}\text { Pretest } \\
(\mathrm{N}, \%)\end{array}$ & $\begin{array}{l}\text { Posttest } \\
(\mathrm{N}, \%)\end{array}$ \\
\hline \multirow{2}{*}{$\begin{array}{l}\text { 1. As I move from room to room } \\
\text { in my house, I slip or stumble } \\
\text { from clutter of electrical cords, } \\
\text { low furniture, or other things } \\
\text { in my path. (Trips) }\end{array}$} & \multicolumn{2}{|c|}{ Never } & \multicolumn{2}{|c|}{ Rarely } & \multicolumn{2}{|c|}{ Once a week } & \multicolumn{2}{|c|}{$\begin{array}{c}\text { More than once a } \\
\text { week }\end{array}$} \\
\hline & $\begin{array}{c}50 \\
(24.5 \%)\end{array}$ & $\begin{array}{c}84 \\
(41.1 \%)\end{array}$ & $\begin{array}{c}137 \\
(67.1 \\
\%)\end{array}$ & $\begin{array}{c}119 \\
(58.3 \%)\end{array}$ & $\begin{array}{c}12 \\
(5.8 \%)\end{array}$ & $\begin{array}{c}1 \\
(0.4 \%)\end{array}$ & $\begin{array}{c}5 \\
(2.4 \% \\
)\end{array}$ & $\begin{array}{c}\mathbf{0} \\
(\mathbf{0 . 0 \%})\end{array}$ \\
\hline \multirow{2}{*}{$\begin{array}{l}\text { 2. As I move from room to room } \\
\text { in my house there are sturdy } \\
\text { things I can grab to steady } \\
\text { myself if I feel unsteady. } \\
\text { (Handholds) }\end{array}$} & \multicolumn{2}{|c|}{ Everywhere } & \multicolumn{2}{|c|}{ Most places } & \multicolumn{2}{|c|}{ Sometimes } & \multicolumn{2}{|c|}{$\begin{array}{c}\text { Few things to steady } \\
\text { me }\end{array}$} \\
\hline & $\begin{array}{c}35 \\
(17.1 \%)\end{array}$ & $\begin{array}{c}78 \\
(38.2 \%)\end{array}$ & $\begin{array}{c}50 \\
(24.5 \\
\%)\end{array}$ & $\begin{array}{c}90 \\
(44.1 \%)\end{array}$ & $\begin{array}{c}40 \\
(19.6 \%)\end{array}$ & $\begin{array}{c}20 \\
(9.8 \%)\end{array}$ & $\begin{array}{c}79 \\
(38.7 \%)\end{array}$ & $\begin{array}{c}16 \\
(7.8 \%)\end{array}$ \\
\hline \multirow{2}{*}{$\begin{array}{l}\text { 3. I have a good light when I } \\
\text { walk in my house, }\end{array}$} & \multicolumn{2}{|c|}{ Always } & \multicolumn{2}{|c|}{ Almost always } & \multicolumn{2}{|c|}{ Sometimes } & \multicolumn{2}{|c|}{ Often dark } \\
\hline & $\begin{array}{c}50 \\
(24.5 \%)\end{array}$ & $\begin{array}{c}84 \\
(41.1 \%)\end{array}$ & $\begin{array}{c}137 \\
(67.1 \\
\%)\end{array}$ & $\begin{array}{c}119 \\
(58.3 \%)\end{array}$ & $\begin{array}{c}12 \\
(5.8 \% \\
)\end{array}$ & $\begin{array}{c}1 \\
(0.4 \%)\end{array}$ & $\begin{array}{c}5 \\
(2.4 \% \\
)\end{array}$ & $\begin{array}{c}0 \\
(0.0 \%)\end{array}$ \\
\hline \multirow{2}{*}{$\begin{array}{l}\text { 4. While inside my home I walk } \\
\text { in shoes, not barefoot or in } \\
\text { slippers. (Footwear) }\end{array}$} & \multicolumn{2}{|c|}{ Often } & \multicolumn{2}{|c|}{ Usually } & \multicolumn{2}{|c|}{ Sometimes } & \multicolumn{2}{|c|}{ Mostly barefoot } \\
\hline & $\begin{array}{c}137 \\
(67.1 \%)\end{array}$ & $\begin{array}{c}119 \\
(58.3 \%)\end{array}$ & $\begin{array}{c}50 \\
(24.5 \\
\%)\end{array}$ & $\begin{array}{c}84 \\
(41.1 \%)\end{array}$ & $\begin{array}{c}5 \\
(2.4 \% \\
)\end{array}$ & $\begin{array}{c}\mathbf{0} \\
(\mathbf{0 . 0 \%})\end{array}$ & $\begin{array}{c}12 \\
(5.8 \%)\end{array}$ & $\begin{array}{c}1 \\
(0.4 \%)\end{array}$ \\
\hline \multirow{2}{*}{$\begin{array}{l}\text { 5. I slip or have difficulty getting } \\
\text { on and off the toilet. (Toilet) }\end{array}$} & \multicolumn{2}{|c|}{ Never } & \multicolumn{2}{|c|}{ Rarely } & \multicolumn{2}{|c|}{ Once a week } & \multicolumn{2}{|c|}{ Often } \\
\hline & $\begin{array}{c}24 \\
(11.7 \%)\end{array}$ & $\begin{array}{c}15 \\
(20.4 \%)\end{array}$ & $\begin{array}{c}50 \\
(24.5 \\
\%)\end{array}$ & $\begin{array}{c}119 \\
(58.3 \%)\end{array}$ & $\begin{array}{c}90 \\
(44.1 \\
\%)\end{array}$ & $\begin{array}{c}50 \\
(24.5 \%)\end{array}$ & $\begin{array}{c}40 \\
(19.6 \%)\end{array}$ & $\begin{array}{c}20 \\
(9.8 \%)\end{array}$ \\
\hline \multirow{2}{*}{$\begin{array}{l}\text { 6. I slip or have difficulty getting } \\
\text { in and out of the bath or } \\
\text { shower. (Bath) }\end{array}$} & \multicolumn{2}{|c|}{ Never } & \multicolumn{2}{|c|}{ Rarely } & \multicolumn{2}{|c|}{ Once a week } & \multicolumn{2}{|c|}{ Often } \\
\hline & $\begin{array}{c}24 \\
(11.7 \%)\end{array}$ & $\begin{array}{c}15 \\
(20.4 \%)\end{array}$ & $\begin{array}{c}50 \\
(24.5 \% \\
)\end{array}$ & $\begin{array}{c}119 \\
(58.3 \\
\%) \\
\end{array}$ & $\begin{array}{c}90 \\
(44.1 \% \\
)\end{array}$ & $\begin{array}{c}50 \\
(24.5 \%)\end{array}$ & $\begin{array}{c}40 \\
(19.6 \%)\end{array}$ & $\begin{array}{c}20 \\
(9.8 \%)\end{array}$ \\
\hline \multirow{2}{*}{$\begin{array}{l}\text { 7. I slip or have difficulty with } \\
\text { steps or stairs in my house. } \\
\text { (Stairs) }\end{array}$} & \multicolumn{2}{|c|}{ Never } & \multicolumn{2}{|c|}{ Rarely } & Onc & week & & en \\
\hline & $\begin{array}{c}20 \\
(9.8 \%)\end{array}$ & $\begin{array}{c}40 \\
(19.6 \%)\end{array}$ & $\begin{array}{c}50 \\
(24.5 \% \\
\quad\end{array}$ & $\begin{array}{c}90 \\
(44.1 \\
\%)\end{array}$ & $\begin{array}{c}119 \\
(58.3 \% \\
)\end{array}$ & $\begin{array}{c}50 \\
(24.5 \%)\end{array}$ & $\begin{array}{c}15 \\
(20.4 \% \\
)\end{array}$ & $\begin{array}{c}24 \\
(11.7 \% \\
)\end{array}$ \\
\hline 8. I stand on my toes to get things & & & & & Som & mes & & \\
\hline closets (Reach) & $\begin{array}{c}35 \\
(17.1 \%)\end{array}$ & $\begin{array}{c}78 \\
(38.2 \%)\end{array}$ & $\begin{array}{c}50 \\
(24.5 \% \\
)\end{array}$ & $\begin{array}{c}90 \\
(44.1 \\
\%) \\
\end{array}$ & $\begin{array}{c}40 \\
(19.6 \%)\end{array}$ & $\begin{array}{c}20 \\
(9.8 \%)\end{array}$ & $\begin{array}{c}79 \\
(38.7 \%)\end{array}$ & $\begin{array}{c}16 \\
(7.8 \%)\end{array}$ \\
\hline $\begin{array}{l}\text { 9. In the places I walk outside, } \\
\text { there are uneven surfaces, }\end{array}$ & & & & & Son & imes & & en \\
\hline $\begin{array}{l}\text { steps, or other problems that } \\
\text { make me trip or stumble. } \\
\text { (Outside) }\end{array}$ & $\begin{array}{c}50 \\
(24.5 \%)\end{array}$ & $\begin{array}{c}84 \\
(41.1 \%)\end{array}$ & $\begin{array}{c}137 \\
(67.1 \% \\
)\end{array}$ & $\begin{array}{c}119 \\
(58.3 \\
\%)\end{array}$ & $\begin{array}{c}12 \\
(5.8 \%)\end{array}$ & $\begin{array}{c}1 \\
(0.4 \%)\end{array}$ & $\begin{array}{c}5 \\
(2.4 \% \\
)\end{array}$ & $\begin{array}{c}0 \\
(0.0 \%)\end{array}$ \\
\hline $\begin{array}{l}\text { 10.If I were to fall, hurt myself, } \\
\text { and were unable to get up, I }\end{array}$ & & & & & Som & mes & No-Ust & lly alone \\
\hline $\begin{array}{l}\text { would be able to get help } \\
\text { quickly. (Help) }\end{array}$ & $\begin{array}{c}20 \\
(9.8 \%)\end{array}$ & $\begin{array}{c}40 \\
(19.6 \%)\end{array}$ & $\begin{array}{c}50 \\
(24.5 \% \\
)\end{array}$ & $\begin{array}{c}90 \\
(44.1 \\
\%)\end{array}$ & $\begin{array}{c}119 \\
(58.3 \\
\%)\end{array}$ & $\begin{array}{c}\mathbf{5 0} \\
(\mathbf{2 4 . 5 \%})\end{array}$ & $\begin{array}{c}15 \\
(20.4 \\
\%)\end{array}$ & $\begin{array}{c}24 \\
(11.7 \% \\
)\end{array}$ \\
\hline
\end{tabular}

Table 2: Demonstrated an increase in the elderly home safety level between pre and postinterventions as percentage of elderly people who had once a week slipping or having 
difficulty getting in and out of the bath or shower decreased from $44.1 \%$ in pretest to $24.5 \%$ in posttest.

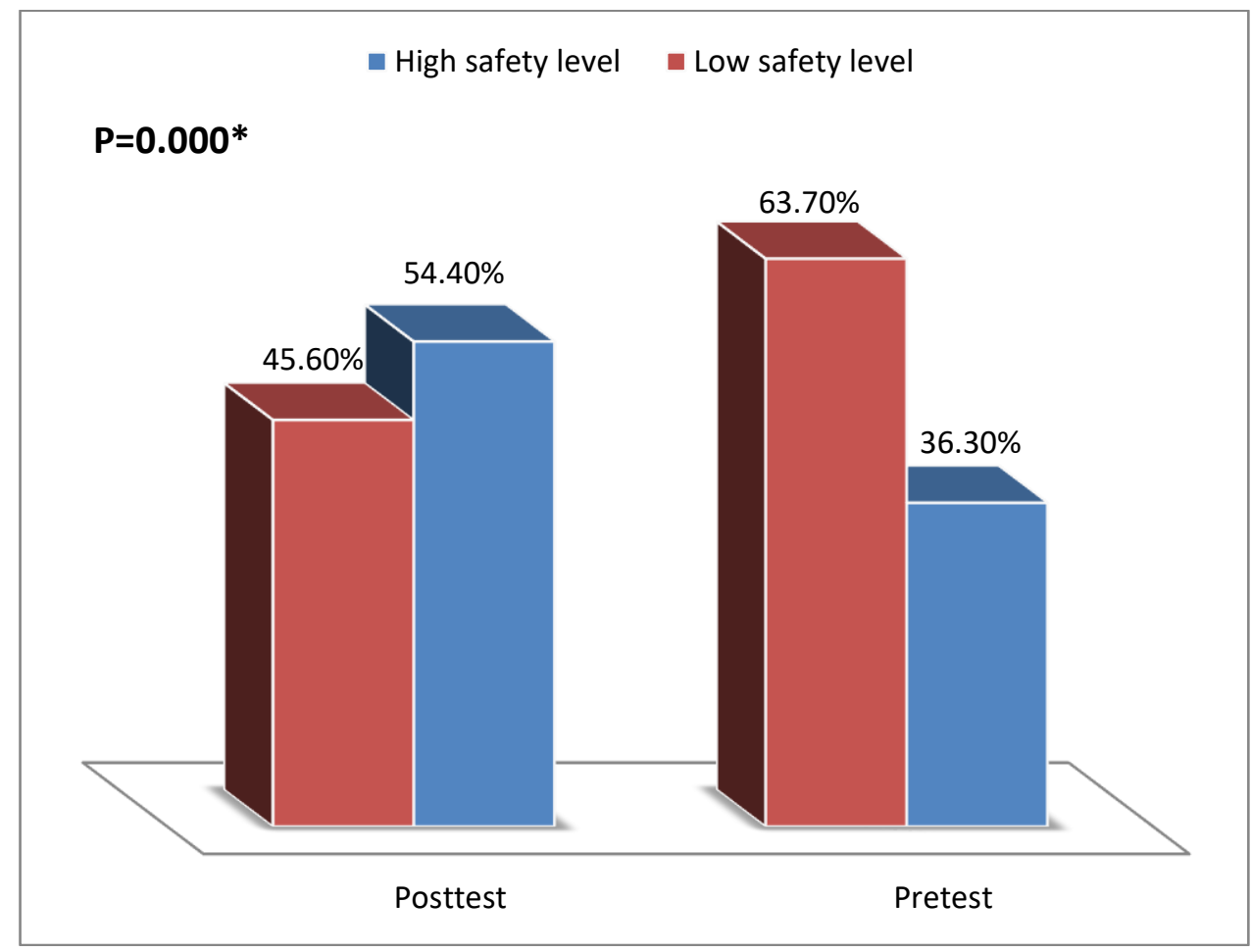

Figure (1): Comparison between home safety level of the studied elderly at pre and posttest.

Figure 1: illustrated statistically significant difference between pre $\&$ posttest for the studied sample regarding their home safety level reflected with $\mathrm{P}=0.000$, as high home safety level increased from $36.3 \%$ at pretest to $54.4 \%$ at posttest.

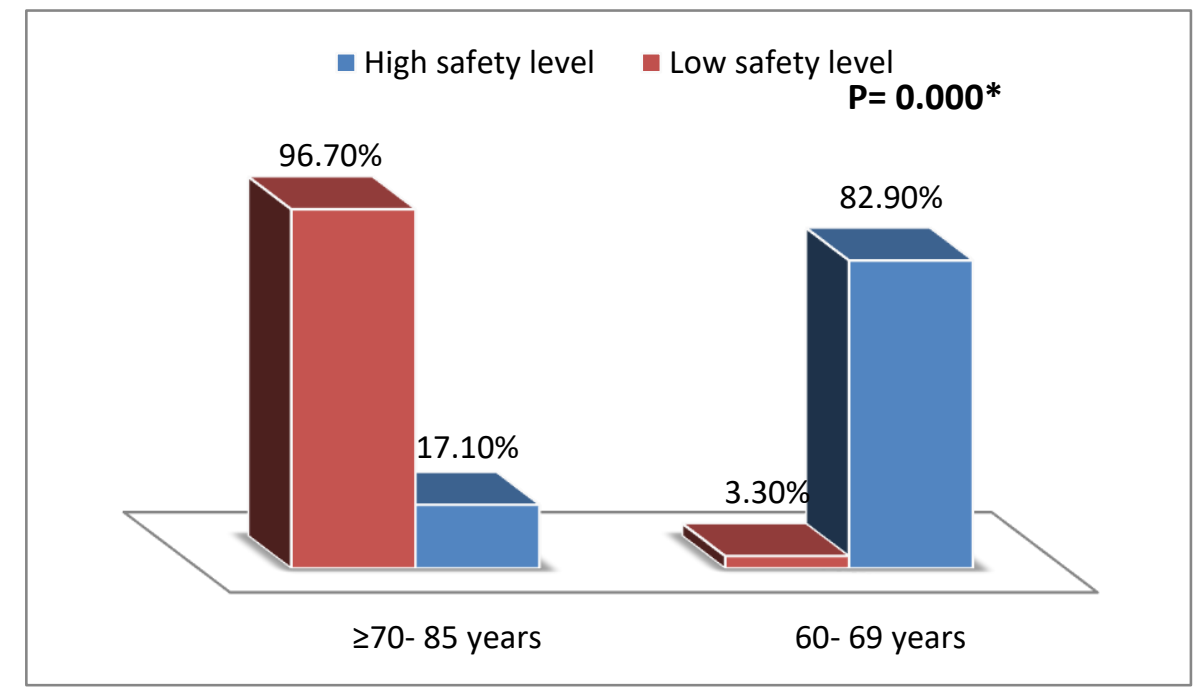

Figure (2): Home safety level of the studied sample in relation to their age. 
Figure 2: Showed a statistically significant difference between home safety level at pre and posttest among participants in relation to their age group with $\mathrm{p}$ value $=0.000$, in which a significant elevation of home safety level was shown among the age group of (60-69 years).

Table (3): Relation between home safety level of participants and the environmental components before and after the guidelines application

\begin{tabular}{|c|c|c|c|c|c|c|c|c|}
\hline \multirow{4}{*}{$\begin{array}{c}\text { Environmental } \\
\text { component \# }\end{array}$} & \multicolumn{8}{|c|}{ Home safety level } \\
\hline & \multicolumn{4}{|c|}{ High safety level } & \multicolumn{4}{|c|}{ Low safety level } \\
\hline & \multicolumn{2}{|c|}{ Pretest } & \multicolumn{2}{|c|}{ Posttest } & \multicolumn{2}{|c|}{ Pretest } & \multicolumn{2}{|c|}{ Posttest } \\
\hline & No. & $\%$ & No. & $\%$ & No. & $\%$ & No. & $\%$ \\
\hline Bathroom and toilets & 11 & 5.4 & 36 & 17.6 & 6 & 2.9 & 3 & 1.4 \\
\hline Furniture & 18 & 8.9 & 42 & 20.5 & 14 & 6.8 & 3 & 1.4 \\
\hline Floor surfaces & 12 & 5.8 & 24 & 11.7 & 21 & 10.3 & 7 & 3.4 \\
\hline Lighting & 23 & 11.2 & 56 & 27.4 & 47 & 23.1 & 11 & 5.4 \\
\hline Passageways & 9 & 4.5 & 15 & 7.3 & 8 & 3.9 & 2 & 0.9 \\
\hline External areas & 9 & 4.5 & 15 & 7.3 & 5 & 2.5 & 1 & 0.4 \\
\hline Security of environment & 15 & 7.3 & 45 & 22.0 & 6 & 2.9 & 4 & 1.9 \\
\hline Total & & $56.3+7.6$ & & $5+8.7$ & & $7+6.1$ & & $9+3.2$ \\
\hline P-value & \multicolumn{4}{|c|}{ 0.000* } & \multicolumn{4}{|c|}{$0.000 *$} \\
\hline
\end{tabular}

\# More than one item

*Means there is significant difference

Table 3: showed that there was statistically significant effect between pre, posttest regarding home safety level and each environmental items as bathroom, furniture, floor surfaces and lighting for low and high safety level $\mathrm{P}=0.000$. 
Table (4): Relationship between demographic characteristics of the studied elderly and their home safety level at pre and posttest.

\begin{tabular}{|c|c|c|c|c|c|c|c|c|c|}
\hline \multirow{4}{*}{$\begin{array}{l}\text { Demographic } \\
\text { characteristics }\end{array}$} & \multicolumn{8}{|c|}{ Home safety } & \multirow{4}{*}{$\begin{array}{c}\text { P-value } \\
2\end{array}$} \\
\hline & \multicolumn{4}{|c|}{ High safety level } & \multicolumn{4}{|c|}{ Low safety level } & \\
\hline & \multicolumn{2}{|c|}{$\begin{array}{l}\text { Pretest } \\
(\mathrm{N}=74)\end{array}$} & \multicolumn{2}{|c|}{$\begin{array}{l}\text { Posttest } \\
(\mathrm{N}=111)\end{array}$} & \multicolumn{2}{|c|}{$\begin{array}{l}\text { Pretest } \\
(\mathrm{N}=130)\end{array}$} & \multicolumn{2}{|c|}{$\begin{array}{c}\text { Posttest } \\
(\mathrm{N}=93)\end{array}$} & \\
\hline & No. & $\%$ & No. & $\%$ & No. & $\%$ & No. & $\%$ & \\
\hline \multicolumn{10}{|l|}{ Age } \\
\hline 60- 69 years & 64 & 86.5 & 92 & 82.9 & 31 & 23.8 & 3 & 3.2 & \multirow{3}{*}{$0.000 *$} \\
\hline$\geq 70-85$ years & 10 & 13.5 & 19 & 17.1 & 99 & 76.2 & 90 & 96.8 & \\
\hline P-value 1 & \multicolumn{4}{|c|}{$0.543 \mathrm{~ns}$} & & & & & \\
\hline \multicolumn{10}{|l|}{ Gender } \\
\hline Female & 72 & 97.3 & 98 & 88.3 & 51 & 39.2 & 25 & 26.9 & \multirow{3}{*}{$0.055 \mathrm{~ns}$} \\
\hline Male & 2 & 2.7 & 13 & 11.7 & 79 & 60.8 & 68 & 73.1 & \\
\hline P-value 1 & \multicolumn{4}{|c|}{ 0.000* } & & & & & \\
\hline \multicolumn{10}{|l|}{ Residence } \\
\hline Urban & 30 & 40.5 & 66 & 59.5 & 38 & 29.2 & 30 & 32.3 & \multirow[b]{2}{*}{$0.099 \mathrm{~ns}$} \\
\hline Rural & 44 & 59.5 & 45 & 40.5 & 92 & 70.8 & 44 & 67.7 & \\
\hline P-value 1 & \multicolumn{4}{|c|}{ 0.011* } & & & & & \\
\hline \multicolumn{10}{|l|}{ Education } \\
\hline Illiterate & 44 & 59.5 & 106 & 95.5 & 119 & 91.5 & 57 & 61.3 & \multirow{4}{*}{$0>000 *$} \\
\hline Read and Write & 17 & 22.9 & 2 & 1.8 & 8 & 6.2 & 23 & 24.7 & \\
\hline Secondary & 10 & 13.5 & 1 & 0.9 & 2 & 1.6 & 11 & 11.8 & \\
\hline University & 3 & 4.1 & 2 & 1.8 & 1 & 0.7 & 2 & 2.2 & \\
\hline P-value 1 & \multicolumn{4}{|c|}{$0>000 *$} & & & & & \\
\hline
\end{tabular}

*Means there is significant difference

P-value 1 relation between pretest \& posttest for high safety level

P-value 2 relation between pretest \& posttest for low safety level

Table 4: illustrated that there was statistically significant effect between residence, educational level and safety level of the studied sample $\mathrm{P}=0.000 \mathrm{P}=0.000$ respectively.

\section{Discussion:}

Worldwide populace is maturing; especially in developing nations. The advancement of the lodging environment of the elderly is one of the key components in their quality of life. Maintaining elderly people living in a harmless home environment became a global concern. Nurses play an essential role in this health issue through performing home assessment, safety modification, and designing health educational programs that aimed to decreasing domestic dangers and ensuring their security and well-being (10). 
Regarding the demographic characteristics of the studied sample, it was found that $53.4 \%$ of the studied group aged 60-69 years old, with mean age was $70.4 \pm 7.0$, this was in agreement with ${ }^{(11)}$ who found that most the studied sample were in the age 60-69 years with mean age $76.4 \pm 7.8$.

The present study revealed that there was statistically significant effect between the age of the studied sample and their home safety level, as the percent of elderly participants aged 60-69 years achieved high home safety level in contrast to elderly participants aged 70 years and more, this may be due to the fact that as people age became less able to maintained their safety housing conditions due to their functional status impairment compared to younger ones. This findings was disagrees with ${ }^{(\mathbf{1 2})}$ who reported that there was no statistically significant effect between age of the studied sample and their home safety level.

Regarding gender, it was illustrated that three fifths of the study group were females, this agrees with ${ }^{\mathbf{1 3}}$ who reported that the majority of the studied sample were females. Concerning the level of education it was observed that nearly four fifths of the study group were illiterate this is similar to ${ }^{(4)}$ who founded that the majority of respondents had were of a low literacy rate.

Also, the current study showed a statistical significant relation between the educational level of the studied sample and their home safety level, as the vast majority of illiterate participants achieved low safety level, this can be discussed as the educated people had health awareness regarding to their home health conditions and are aware about age related needs in reverse to illiterate ones. This fact was supported by ${ }^{(5)}$ who found that low safety level detected among uneducated elderly people compared to those with higher educational attainment. Similarly, another validation by ${ }^{(6)}$ documented significant difference between education level \& safety in which elderly safety at home was higher among the educated elderly people.

The results of this study supported research hypothesis, as results demonstrated improvement in elderly home safety after the application of home management guidelines with statistical significant differences between pre and posttest. It was revealed that the percent of elderly people who had once a week slipping or having difficulty getting in and out of the bath or shower significantly decreased in posttest as compared to before. This was 
matching with 4 who reported that the elderly participants had less difficulty post intervention than pre intervention. Also, these findings were in the same line with ${ }^{(5 \& 15)}$ who reported that home intervention improved elderly safety level.

The current study illustrated that there was a statistical significant difference between pre and posttest regarding home safety level and each environmental items as; bathroom, furniture, floor surfaces and lighting for low and high safety level. This agrees with ${ }^{(16)}$ who reported that respondents with environmental hazardous items were significantly more likely to report low home safety level.

The present study revealed an improvement in elderly walking outside in posttest than pretest and a decrease in falling episodes among them in posttest than pretest; this is similar to the finding of ${ }^{(\mathbf{1 7})}$ who reported a statistically significant association between home safety level and falling among elderly people. Also, ${ }^{(18)}$ reported that high home safety level of elderly people was associated with significant effects on the ability to manage their own health and on the overall functional activities.

\section{Conclusion}

Numerous seniors are living in potentially unsafe environment and the application of environmental management guidelines was effective in increasing their home safety level.

\section{Recommendations:}

- Personalized home programs for environmental risk factor screening and educational intervention focusing on home hazard assessment and modifications.

- Health education programs for elderly caregivers about home needs and safety measures for elderly.

- Regular use of elderly home safety checklists can help implement an effective elderly fall prevention program.

- More authoritative work in this zone should be carried out.

\section{References:}

1. World Health Organization (2019). World Health Statistics available at: http://www.who.int/gho/publications/world_health_statistics. 
2. Egyp Demographics

Profile

(2019).

Available

at:https://www.indexmundi.com/egypt/demographics_profile.html.

3. Home Safety Council (2021). Available at: http://www.homesafetycouncil.org/

4. Szanton S., Leff B., Wolff J., Roberts L. \& Gitlin N. (2016). Home-Based Care Program Reduces Disability and Promotes Aging In Place. Health Aff (Millwood); 35(9):1558-1563.

5. Junprateep C., Seviset S., \& Eakwutvongsa S. (2020). Guideline for Innovation Management Design of Home Bathroom Environment to Help Reduce Accident Risk among Elderly.Mediterranean Journal of Social Sciences; 11(2): 33-33.

6. Elsamahy EA, ELSayed EM, \& BadrEldin SA. (2019): Risk Factors for fall among Elderly in a Rural Community in El-Monofya Governorate. Saudi Journal of Nursing and Health Care; 2(1): 1-14.

7. Kattab S. \& Abd El-.Rahman S., (2013). Assessment of Home Safety Measures and Prevalence of Falling among Residents of Private and Governmental Elderly Homes in two Different Societies in Egypt. J Am Sci; 9(9):343-357.

8. Tomita M, Saharan S, Rajendran S, Schweitzer J. \& Nochajski S. (2014). American Journal of Occupational Therapy, 68 (6): 711-718.

9. Michael W., Penny B., Carol C., \& Denise K., (2013). Validation of a home safety questionnaire used in a series of case-control studies, Injury Prevention 20(5).

10. Moncatar T., Nakamura K., Siongco K., Rahman M. \& Seino K. (2020). Prevalence and Determinants of SelfReported Injuries among CommunityDwelling Older Adults in the Philippines: A 10-Year Pooled Analysis. International Journal of environmental research and public health, 17(12), 4372.

11. Sarah L., Qian-L., Bruce L., \& Jack G., (2019). Effect of a Biobehavioral Environmental Approach on Disability Among Low-Income Older Adults A Randomized Clinical Trial, JAMA Intern Med. 9; 179(2):204-211. 9.

12. Szanton SL, Wolff JW, \& Leff B, (2014); CAPABLE trial: a randomized controlled trial of nurse, occupational therapist and handyman to reduce disability among older adults: rationale and design. Contemp Clin Trials.; 38(1):102-112.

13. Thorpe RJ, Boyd C, \& Szanton, SL (2011). Community aging in place, advancing better living for elders: a bio-behavioral-environmental intervention to improve function and health-related quality of life in disabled older adults. J Am Geriatr Soc. 2011; 59(12):2314-2320. 
14. Szanton S., Leff B., Wolff J., Roberts L., \& Gitlin L. (2016). Home-Based Care Program Reduces Disability And Promotes Aging In Place. Health Aff (Millwood). $2016 ; 35(9)$

15. Freedman VA., and Spillman BC. (2014). The residential continuum from home to nursing home: size, characteristics and unmet needs of older adults. J Gerontol B Psychol Sci Soc Sci. 2014; 69.

16. Cho J, Cook C, \& Bruin M. (2018). Functional ability, neighborhood resources and housing satisfaction among older adults in the U.S.J Hous Elder. 2018;26 (4):395-412.

17. Arnau A, Espaulella J, Serrarols M, Canudas J, Formiga F, \& Ferrer M. (2016). Risk factors for functional decline in a population aged 75 years and older without total dependence: A one-year follow-up. Arch Gerontol Geriatr. 2016;65:239247.

18. Ruiz S, Snyder LP, Rotondo C, Cross-Barnet C, Colligan EM, \& Giuriceo K. (2017).Innovative home visit models associated with reductions in costs, hospitalizations, and emergency department use. Health Aff (Millwood). 2017; $36(3): 425-432$. 